\title{
Befriende ord fra legen
}

\author{
«Som snørr fra øynene,» sa fast- \\ legen til meg. Det var de fineste \\ ordene jeg hadde hørt på lenge
}

Noen måneder etter at tvillingjentene mine hadde begynt i barnehagen, for et par år siden, skjedde det som måtte skje: En epidemi av øyekatarr oppsto på småbarnsavdelingen. I kjøleskapet sammen med barnas matpakker lå det plutselig flere små flasker antibiotikadråper med ulike barns navn på.

Senere samme uke, etter et møte på jobb, hadde jeg et tapt anrop fra barnehagen på mobilen. Jeg ringte opp og fikk vite at mannen min allerede hadde hentet barna.

- Hva gjaldt det, da? spurte jeg.

- Puss fra øynene. Dere bør nok få øyedråper fra legen, lød svaret.

Barnehagen er super og de ansatte der er flinke i jobben sin og glad i barna. Jeg hadde lite lyst til å være den vanskelige moren som omtrent fra første stund begynte å snakke om utdaterte retningslinjer og slå i bordet med forskningsresultater. Samtidig syntes jeg ikke at jeg kunne la være å si noe.

Litt motvillig tok jeg barna med til fastlegen. Jeg forklarte situasjonen med barnehagen som anbefalte behandling og sa at jeg ikke egentlig var bekymret for øyekatarren. Det var da hun sa de «magiske» ordene:

- Øyekatarr er som en forkjølelse, det gule pusset er som snørr fra øynene. Man behandler ikke forkjølelse med antibiotika.
Er de ellers i fin form, kan barna gå i barnehagen. Bare tørk bort «snørra».

Det var de fineste ordene jeg hadde hørt på lenge. Fine fordi de var så enkle og beskrivende, så lette å bringe videre.

- Fikk du øyedråper? spurte de ansatte da jeg tok med meg jentene tilbake til barnehagen.

- Nei, fastlegen mente det ikke var nødvendig. Hun forklarte det på en veldig fin måte, svarte jeg.

Med selvtillit kunne jeg gjenta fastlegens budskap overfor den lille forsamlingen, som lot til å ta det innover seg. Siden har jeg delt den enkle forklaringen med mange flere, blant andre ABC Nyheters lesere.

Og da en av jentene mine nylig hadde sesongens første runde med øyekatarr, var det hele over etter en ukes tid - helt uten telefon fra barnehagen, legebes $\varnothing \mathrm{k}$ eller antibiotikadråper og uten at det så ut til å plage treåringen noe mer enn en forkjølelse med snørr bare fra nesen.

Medisin er vanskelig for oss vanlige dødelige, og da er det ekstra deilig når noe kan sies så enkelt og fremdeles være riktig. Som mor er det lett å forklare for treåringene at kroppen ikke blir glad hvis man spiser is hver dag, hele året. Det er selvfølgelig unyansert, men ikke helt feil og fungerer i hvert fall ganske greit for dette publikummet. (Litt mer komplisert blir det vel når de som fireåringer krever å få vite «Hvorfor det?».) Men avislesere krever naturligvis og heldigvis mer enn treåringer. Som helsejournalist er det ofte utfordrende å skrive om kompliserte temaer, enkelt nok til at leserne forstår at det er viktig og får lyst til å lese videre, samtidig som det er presist nok til at det medfører riktighet.

Jeg vet at dere som er leger og forskere, og våre kilder, av og til leller kanskje til og med ofte?) rister på hodet over journalistenes overforenklinger og deskens altfor tabloide vinklinger på saker som burde være langt mindre lettbeinte. Andre ganger får man med rette kjeft fra journalistkolleger for at språket i avisartikkelen er preget av den vitenskapelige artikkelen man har lest og refererer til.

I en drømmeverden tar vi journalister og fagpersoner oss i samarbeid litt ekstra tid til å forenkle der det er mulig, for å gjøre det kompliserte litt mindre vanskelig og så interessant som vi vet at helse og medisin er.

Alt kan ikke sies like enkelt som «snørr fra øynene». Men et eller annet sted, mellom det tunge fagspråket i vitenskapelige tidsskrifter og det unyanserte i de mest overfladiske avisartiklene, kan vi kanskje litt oftere finne de magiske ordene som vil glede både fagfolk og journalister - og ikke minst leserne.

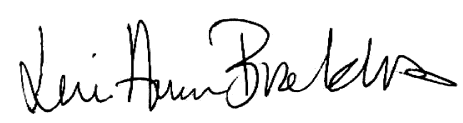

